\title{
Correction to: Corrosion Resistant Boron-Modified Ferritic and Austenitic Stainless Steels Designed by CALPHAD
}

\author{
E.R. DOS SANTOS, W.A. DA SILVA, G.Y. KOGA, C. BOLFARINI, and G. ZEPON
}

https://doi.org/10.1007/s11661-021-06290-w

(C) The Minerals, Metals \& Materials Society and ASM International 2021

CORRECTION TO:

METALLURGICAL AND MATERIALS

TRANSACTIONS A

HTTPS://DOI.ORG/10.1007/S11661-021-06226-4

IN the original online version of the article there was an error in the legend of Fig. 10a. The original article has been corrected.
Publisher's Note Springer Nature remains neutral with regard to jurisdictional claims in published maps and institutional affiliations.

E.R. DOS SANTOS is with the Graduate Program in Materials Science and Engineering, Federal University of Sao Carlos, Rod. Washington Luiz, km 235, Sao Carlos, SP, 13565-905, Brazil. W.A. DA SILVA and G.Y. KOGA are with the Department of Materials Engineering, Federal University of Sao Carlos, Rod. Washington Luiz, km 235, Sao Carlos, SP, 13565-905, Brazil. C. BOLFARINI and G. ZEPON are with the Graduate Program in Materials Science and Engineering, Federal University of Sao Carlos and also with the Department of Materials Engineering, Federal University of Sao Carlos. Contact e-mail: zepon@ufscar.br

The original article can be found online at https://doi.org/10.1007/ s11661-021-06226-4.

Article published online May 3, 2021 